\title{
Coexistence of halloysite and kaolinite - a study on the genesis of kaolin clays of Campo Alegre Basin, Santa Catarina State, Brazil
}

\author{
MARISA T.G. DE OLIVEIRA ${ }^{1}$, SANDRA M.A. FURTADO ${ }^{2}$, MILTON L.L. FORMOSO ${ }^{3}$, \\ RICHARD A. EGGLETON ${ }^{4}$ and NORBERTO DANI ${ }^{3}$ \\ ${ }^{1}$ Universidade Federal do Rio Grande do Sul, Instituto de Geociências, Av. Bento Gonçalves, 9500 \\ 91509-900 Porto Alegre, RS, Brasil \\ ${ }^{2}$ Universidade Federal de Santa Catarina, Trindade - 88040-970 Florianópolis, SC, Brasil \\ ${ }^{3}$ Centro de Estudos em Petrologia e Geoquímica, Instituto de Geociências, Universidade Federal do Rio Grande do Sul \\ Av. Bento Gonçalves, 9500 - 91509-900 Porto Alegre, RS, Brasil \\ ${ }^{4}$ Department of Earth and Marine Sciences, DEMS Building 047, Australian National University, ACT 0200 Australia \\ Manuscript received on October 13, 2005; accepted for publication on September 10, 2006; \\ contributed by MiLTON L.L. Formoso*
}

\begin{abstract}
Kaolin at Campo Alegre Basin, Santa Catarina State, Brazil was formed from alteration of volcanic acid rocks. Halloysite clays dominate the clay fraction of the matrix of the kaolin body, whereas a poorly crystalline kaolinite is abundant in veins. Some primary blocky structures have high amounts of illite, in one mine, but in general, only low contents of illite-smectite, illite, chlorite-vermiculite, vermiculite and quartz were identified in the clay fraction of the samples. Toward the top of the mines, hematite and lepidocrocite appear in horizontal red and ochre colored levels and the amount of kaolinite increases compared to halloysite. The vertical zoning of alteration levels, the changes in mineralogy, the positive correlation between depth and Cation Exchange Capacity of the clays, the preservation of different types of rock textures in the kaolin bodies, the dominant tube morphology of the halloysite clays indicate a supergene genesis for the deposits. Criteria to distinguish between supergene and hypogene kaolin are discussed. Transmission Electron Microscopy of the cross sections of halloysite tubes showed polygonal forms that are ascribed to be transitional between kaolinite and halloysite. It is proposed that some of the kaolinite of these deposits be inherited from the dehydration of halloysite tubes.
\end{abstract}

Key words: kaolinite, halloysite, halloysite morphology, kaolin, weathering, clay genesis.

\section{INTRODUCTION}

Campo Alegre Basin is an important source of clays for the ceramic market of the Mercosul and a place of a welldeveloped ceramic industry; however, these clays have been little studied. Kaolin deposits of Campo Alegre Basin resulted from the alteration of acid rocks of the upper volcanic unit of Campo Alegre Formation (Neoproterozoic). The bedrock is composed of rhyolitic and trachytic lava interspersed with pyroclastic material ei-

* Member Academia Brasileira de Ciências

Correspondence to: Marisa Terezinha Garcia de Oliveira

E-mail: marisa.oliveira@ufrgs.br ther coarse or thinly laminated (Ebert 1971, Daitx and Carvalho 1980). The origin of these deposits is controversial: Biondi et al. (1999) stated they were formed by hydrothermal activity; Oliveira et al. (2000) showed coexistence of halloysite and kaolinite in one mine of the deposit and also showed evidences of a supergene origin. Few data on the mineralogy, chemistry and morphology of the clays are available.

The objectives of this work are:

- To identify and characterize the kaolin clays of this basin (location, macroscopic characteristics, min- 
eralogy, chemistry, cation exchange capacity, morphology) applying several methods which is useful for mineral exploration.

- Present new data on the crystal morphology of the kaolin clays of this deposit, and in particular to describe transitional forms between halloysite and kaolinite, and implications for the interpretation of geological history.

\section{LOCATION AND GEOLOGICAL SETTING}

Kaolin was formed from the alteration of volcanic acid rocks, near São Bento do Sul, Santa Catarina State, Brazil (Fig. 1). These rocks are components of Campo Alegre volcanic-sedimentary basin (Citroni et al. 2001) of almost $400 \mathrm{~km}^{2}$. It is a Neoproterozoic sequence $(595 \pm$ $16 \mathrm{Ma}$, Cordani et al. 1999) lying on older Archean granulite terranes. Rhyolite is the most abundant lithotype (Weischel et al. 2000), but the rocks are heterogeneous: trachytes, porphyritic rhyolites, banded rhyolites, tuffs, breccia. The Lower Effusive Sequence is composed of basalt and trachyte. The Intermediary Epiclastic-volcanoclastic Sequence is made of shale and volcanogenic sedimentary and pyroclastic flow. The Upper Volcanic Sequence ( $80 \%$ of the exposed area) of late Proterozoic age consists of trachytes and rhyolites. Pyroclastic flow deposits are common as welded high temperature ignimbrites (Weischel et al. 2000). Old rocks in a plateau up to $\pm 1000 \mathrm{~m}$ above sea level, fractures and faults are evidences of a regional uplift (Potter 1997) in the area. Thick (20-40 m) deposits of clays evolve from the surface rocks. Three kaolin mines in Campo Alegre Basin were studied: Oxford (or Floresta) Mine, Incepa (or Cambuí) Mine and Ceramarte Mine (Table I).

Ceramarte Mine $\left(26^{\circ} 15^{\prime} 21^{\prime \prime} \mathrm{S}-49^{\circ} 12^{\prime} 55^{\prime \prime} \mathrm{W}\right)$ is located in a down-slope landscape near the centre of Campo Alegre Basin. The mine is 7 to 17 meters deep and exposes differentiated levels over the altered porphyritic rhyolite. At the base the rhyolite alters to a saprolith horizon that maintains the rock texture; the saprock has elongated core boulders and preserves the rhyolite texture and veins of white clays. As the alteration evolves, a network of clayey white segregations becomes denser within a light pink matrix and the rock texture disappears. An oxidate facies with yellow and red spots develops in the clay zone about 3 to 7.5 meters up. The clay zone has anastomosing veins composed of white clays. Black organic soil develops over the white clays.

Incepa Mine $\left(26^{\circ} 17^{\prime} 27^{\prime \prime} \mathrm{S}-49^{\circ} 16^{\prime} 48^{\prime \prime} \mathrm{W}\right)$ is approximately $30 \mathrm{~m}$ deep. At the base of the mine there are some relicts of the rock (aphanite) in a light greenish gray clayey matrix cut by fractures, coated with white clays. At some points higher in the profile, the matrix shows a very fine (less than $1 \mathrm{~mm}$ ) laminated white and pale red structure with some very coarse (more than $10 \mathrm{~mm}$ ) white granular structures. At the top of the sequence, located in a geomorphic depression, there is a $2 \mathrm{~m}$ thick black-colored soil.

Oxford Mine $\left(26^{\circ} 19^{\prime} 54^{\prime \prime} \mathrm{S}-49^{\circ} 12^{\prime} 50^{\prime \prime} \mathrm{W}\right)$ is the third studied occurrence, in the south of Campo Alegre Basin. Kaolin forms from a banded rock with flow structure planes alternating with more or less clayey material; along the planes there are black coatings. Towards the surface, the rock turns into a white to gray clay with rounded or sub-angular coarse blocky structures (up to $50 \mathrm{~cm}$ diameter) of green clay. Veins coated with white clay cut all the matrix of the mine walls. Higher in the profile, there is a red level ( $1 \mathrm{~m}$ thick) which is followed by an ochre level (1.5 m thick), which in turn is covered by a white clay soil with black roots.

\section{MATERIALS AND METHODS}

Twenty-six samples from the three mines were studied: 7 from Incepa, 8 from Oxford and 11 from Ceramarte Mine. They were split into sub-samples for various methods of investigation.

Thin sections of impregnated samples were studied using scanning electron microscopy.

The clay $(<0.002 \mathrm{~mm})$ fraction of each sample was removed after settling under gravity according to Stock's Law in an aqueous solution of $33 \mathrm{~g}$ of sodium hexametaphosphate and $7 \mathrm{~g}$ of anhydrous sodium carbonate in distilled water (1 liter). Two oriented aggregates of each sample were prepared for Ba saturation and $\mathrm{Mg}$ saturation.

Cation exchange capacity (CEC) was determined by barium saturation as described by Janik and Keeling (1996). The oriented samples saturated with barium (1M $\mathrm{BaCl}_{2}$ ) solution were washed several times with deionized water. Then the samples were dried and analyzed 
TABLE I

Visible differentiation from the walls of each mine, depth, label of the samples, color and description of the profiles.

\begin{tabular}{|c|c|c|c|c|}
\hline \multicolumn{5}{|c|}{ Ceramarte Mine $\left(26^{\circ} 15^{\prime} 21^{\prime \prime} \mathrm{S}-49^{\circ} 12^{\prime} 55^{\prime \prime} \mathrm{W}\right)$} \\
\hline Part of profile & $\begin{array}{l}\text { Depth } \\
\text { (m) }\end{array}$ & $\begin{array}{l}\text { Label of } \\
\text { sample }\end{array}$ & Color of bulk sample & $\begin{array}{c}\text { Description } \\
\text { Top } \rightarrow \text { Base ( } 7 \text { to } 17 \mathrm{~m} \text { deep) }\end{array}$ \\
\hline Upper level & 0.6 & CE7 & White $10 \mathrm{R} 8 / 1$ & Black organic soil over white clays \\
\hline Vein & 1.60 & CE6C & White $10 \mathrm{R} 8 / 1$ & \multirow{2}{*}{$\begin{array}{l}\text { Clay zone with anastomosing veins } \\
\text { composed of white clays }\end{array}$} \\
\hline Matrix & 1.60 & CE6b & White 10R8/1 & \\
\hline Vein & 1.60 & CE6a & White 10R8/1 & \multirow{2}{*}{$\begin{array}{l}\text { An oxidate facies with yellow spots } \\
\text { develops in the clay zone }\end{array}$} \\
\hline Clayey level & 2.70 & CE5a & White 10R8/1 & \\
\hline Vein of the oxidate facies & 3.70 & CE4acd & Yellow $(10$ YR8/6) & \multirow{3}{*}{$\begin{array}{l}\text { The network of clayey white } \\
\text { segregations becomes scarce } \\
\text { within a light pink matrix }\end{array}$} \\
\hline Oxidate facies & 3.70 & CE4bm & Yellow $(10 \mathrm{YR} 8 / 6)$ & \\
\hline Alterite vein & 4.15 & CE3av & Light greenish gray (Gley8/1) & \\
\hline Alterite & 4.15 & CE3bm & White (2.5YR 8/1) & \multirow{3}{*}{$\begin{array}{l}\text { The saprock has elongated core } \\
\text { boulders and preserves the rhyolite } \\
\text { texture and veins of white clays }\end{array}$} \\
\hline Vein of altered rhyolite & 4.80 & CE2bv & Very Pale Brown (10YR8/2) & \\
\hline Altered rhyolite & 4.80 & CE2am & Pink (5YR 7/3) & \\
\hline Rhyolite & 6.30 & CE1av & White (Gley $8 / \mathrm{N})$ & Rhyolite \\
\hline Alterite & 11.65 & CE9 & White & Sample in the sequence \\
\hline \multicolumn{5}{|c|}{ Incepa Mine $\left(26^{\circ} 17^{\prime} 27^{\prime \prime S}-49^{\circ} 12^{\prime} 48^{\prime \prime W}\right)$} \\
\hline Part of profile & $\begin{array}{c}\text { Depth } \\
(\mathrm{m})\end{array}$ & $\begin{array}{l}\text { Label of } \\
\text { sample }\end{array}$ & Color of bulk sample & $\begin{array}{c}\text { Description geomorphic depression } \\
\text { Top } \rightarrow \text { Base (30 m deep) }\end{array}$ \\
\hline Granular structure & 4 & Inc5 & White (Gley $8 / \mathrm{N})$ & \multirow{2}{*}{$\begin{array}{l}2 \mathrm{~m} \text { thick black-colored soil covers } \\
\text { the clays }\end{array}$} \\
\hline Brittle laminated matrix & 5 & Inc $4 b$ & White/pale red (10R 7/2) & \\
\hline Laminated matrix & 5 & Inc4a & White/pale red (10R 7/2) & \multirow{5}{*}{$\begin{array}{l}\text { Saprolite has a very fine (less than } \\
1 \mathrm{~mm} \text { ) laminated white and pale } \\
\text { red structure with some very } \\
\text { coarse (more than } 10 \mathrm{~mm} \text { ) white } \\
\text { granular structures }\end{array}$} \\
\hline Clay Matrix & 7.30 & Inc3 & White (Gley $8 / \mathrm{N})$ & \\
\hline Green indurate relict & 7 & Inc $2 b$ & Light greenish gray (Gley8/10Y) & \\
\hline Gray indurate relict & 7 & Inc2a & Light greenish gray (Gley8/10GY) & \\
\hline \multirow[t]{2}{*}{ Oriented veins } & \multirow[t]{2}{*}{7} & \multirow[t]{2}{*}{ Inc 1} & \multirow[t]{2}{*}{ White (Gley 8/N) } & \\
\hline & & & & $\begin{array}{l}\text { At the base of the mine there are } \\
\text { some relicts of the rock (aphanite) } \\
\text { in a light greenish gray clayey } \\
\text { matrix cut by fractures, coated } \\
\text { with white clays }\end{array}$ \\
\hline \multicolumn{5}{|c|}{ Oxford Mine $\left(26^{\circ} 19^{\prime} 54^{\prime \prime S}-49^{\circ} 12^{\prime} 50^{\prime \prime W}\right)$} \\
\hline Part of profile & $\begin{array}{l}\text { Depth } \\
(\mathrm{m})\end{array}$ & $\begin{array}{l}\text { Label of } \\
\text { sample }\end{array}$ & Color of bulk sample & $\begin{array}{c}\text { Description } \\
\text { Top } \rightarrow \text { Base (20 m deep) }\end{array}$ \\
\hline Soil & 1 & Ox8 & White (Gley $8 / \mathrm{N})$ & White clay soil with black roots \\
\hline Yellow level & 1.5 & Ox7 & Yellowish brown (10YR 5/6) & Ochre level \\
\hline Red level & 2 & Ox6 & Red (2.5YR 5/8) & Red level \\
\hline Matrix & 10 & Ox5 & White (Gley $8 / \mathrm{N})$ & \multirow{5}{*}{$\begin{array}{l}\text { Saprolite is a white to gray clay with } \\
\text { rounded or sub-angular coarse } \\
\text { blocky structures (up to } 50 \mathrm{~cm} \\
\text { diameter) of green clay. Veins } \\
\text { coated with white clay cut all the } \\
\text { matrix of the mine walls }\end{array}$} \\
\hline Vein & 11 & Ox4 & White $($ Gley $8 / \mathrm{N})$ & \\
\hline Matrix & 15 & Ox3 & Light greenish gray (Gley 8/5GY) & \\
\hline Green fragment & 16 & Ox2 & Light greenish gray (Gley 8/5BG) & \\
\hline \multirow[t]{2}{*}{ Rock with flow structure } & \multirow[t]{2}{*}{20} & \multirow[t]{2}{*}{ Ox1 } & \multirow[t]{2}{*}{ Very pale brown (10YR 8/2) } & \\
\hline & & & & $\begin{array}{l}\text { Banded saprock with flow structure } \\
\text { planes alternating with more or } \\
\text { less clayey material; along the } \\
\text { planes there are black coatings }\end{array}$ \\
\hline
\end{tabular}




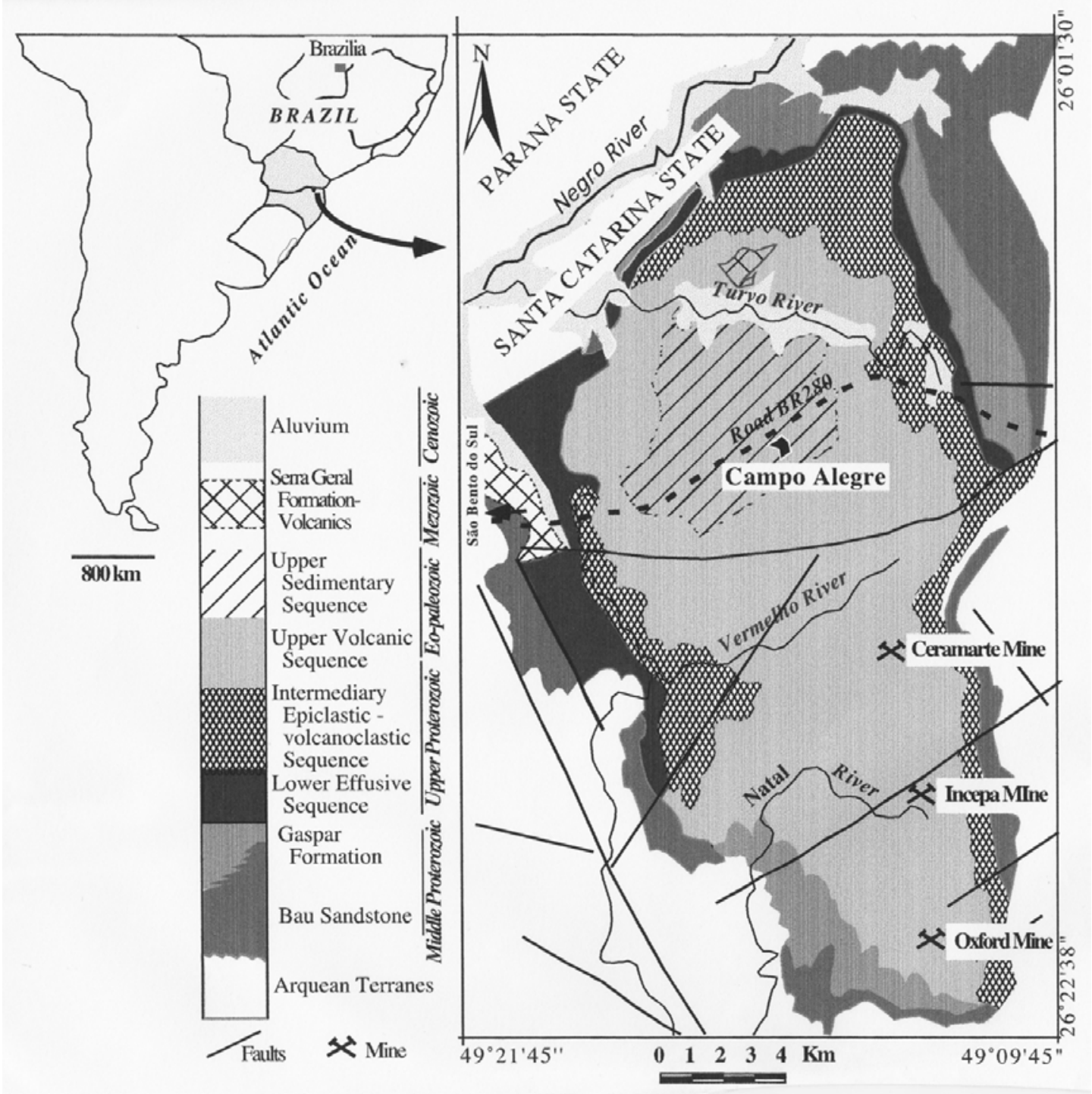

Fig. 1 - Location and geology of Campo Alegre volcanic-sedimentary basin. The Lower Effusive Sequence is composed of basalt and trachyte. The Intermediary Epiclastic-volcanoclastic Sequence is made of shale and volcanogenic sedimentary and pyroclastic flow. The Upper Volcanic consists of trachytes and rhyolites. Three kaolin mines were studied: Oxford (or Floresta) Mine, Incepa (or Cambuí) Mine and Ceramarte Mine.

by XRF to determine barium content and hence CEC.

The Mg saturated samples for X-ray Diffraction analysis were dried in air, ethylene glycol solvated, formamide treated, and heated up to $110^{\circ}, 350^{\circ}$ and $550^{\circ} \mathrm{C}$. Quantitative analyses of the clay separates were done with Siroquant $^{\mathrm{TM}}$ software, using X-ray diffraction of random preparations.

Chemical analyses of 11 bulk samples were obtained with X-ray fluorescence in the Geology Department, ANU.
Clays deposited from ethanol suspension onto aluminum stubs, were dried at $40^{\circ} \mathrm{C}$ and then gold coated $(20 \eta \mathrm{m})$ for observation in a Cambridge S360 SEM with Tracor Northern EDXA.

Analysis of particle shape was made by applying NIH Image software to Adobe PhotoShop images of SEM photomicrographs. From each particle NIH image provided area and the length of the major and minor axes of the best fitting ellipse.

For TEM, small fragments of the samples were im- 


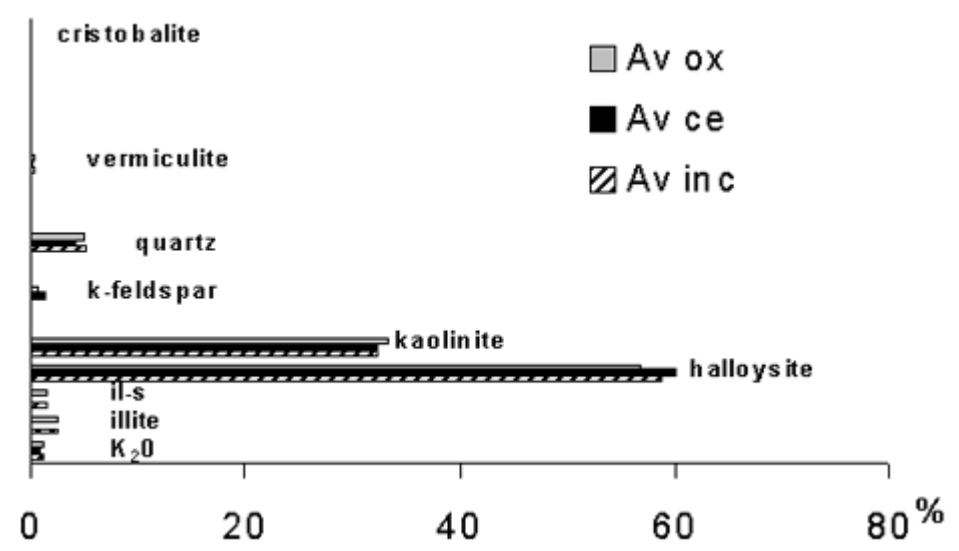

Fig. 2 - The overall distribution of the minerals along the three mines. The lines represent the average of mineral $\%$ in each mine. $\mathrm{Av}=$ average, $\mathrm{Inc}=$ Incepa, $\mathrm{Ce}=$ Ceramarte, $\mathrm{Ox}=$ Oxford.

pregnated with Spurr resin. After two weeks the samples were heated up to $60^{\circ} \mathrm{C}$ for 24 hours, then cut with a Reichelrt ultramicrotome, mounted on copper grids and coated with carbon. A Philips $430 \mathrm{EM}, 300 \mathrm{kV}$ at EMU-ANU and a Philips CM TEM $300 \mathrm{kV}$, Gatan Camera, at the Research School of Earth Sciences (ANU) were used.

\section{RESULTS AND DISCUSSION}

\section{XRD-Mineralogical COMPOSITION}

Data were obtained by quantification on the X-ray diffractograms of random preparations of the clays analyzed with the SIROQUANT software and are shown in Table II as well as the name and the character of the samples (rock, regolith, vein, soil, etc).

In the three kaolin bodies, kaolin minerals halloysite and kaolinite are the main constituents. Exceptions are samples $\mathrm{Ox} 1, \mathrm{Ce} 2 \mathrm{~m}, \mathrm{Ce} 3 \mathrm{~b}$ that correspond to saprocks with high percentages of K-feldspar; sample Ox2 has high percentage of illite. Figure 2 shows the overall distribution of the minerals along the three mines obtained from averages of the \% mineralogy of Table II. Halloysite is the most abundant clay mineral in the three mines. Only in two samples of veins (Ce2av and Inc5, Table II) the amounts of kaolinite are higher than halloysite.

The XRD diffractograms of oriented, air-dried preparations of representative samples of the three mines are presented in Figure 3.
The veins in the rock (rhyolite) of Ceramarte Mine (Fig. 3A-Celav) are composed mostly of halloysite. The saprock (Fig. 3A-2bm) still contains K-feldspar. The veins in the saprock contain kaolinite of a highdefect type (Fig. 3A-Ce3av) with Hinckley Index of 0.6. The upper saprolite (Fig. 3A-Ce7) is made of halloysite, kaolinite and traces of quartz.

Clays from Incepa Mine have illite (Fig. 3B-Inc 2b) in the saprock but not in the veins (Fig. 3B-Inc1); illite totally disappears in the clayey upper levels (Fig. 3BInc4b).

In the Oxford Mine some primary block structures showed high amounts of illite (Fig. 3C-Ox2), but in general, only low contents of illite (aver-2\%), illite-smectite (aver-1.5\%), quartz (aver-5\%), microcline (aver-1\%), vermiculite (aver- $0.4 \%$ ), and chlorite-vermiculite were identified in the clay fraction of the studied samples. The highest $\%$ of kaolinite $(42 \%)$ occurs in the veins (Fig. $3 \mathrm{C}-\mathrm{Ox} 4$ ), and the highest $\%$ of halloysite occurs in the clayey matrix (Fig. 3C-Ox5).

Toward the top of the mines, iron oxides concentrate in a red (hematite) level followed (in Oxford Mine) by an ochre (lepidocrocite) level. Also some other minor mineral components were detected: gibbsite and anatase (Oxford Mine); cristobalite (Ceramarte Mine).

\section{Chemistry of Clays}

XRF analyses of 11 bulk samples of the three mines are shown in Table IIIa. 
TABLE II

The kaolin samples from Campo Alegre Basin.

\begin{tabular}{|c|c|c|c|c|c|c|c|c|c|c|c|c|c|c|}
\hline \multirow[b]{2}{*}{$\begin{array}{l}\text { Oxford } \\
\text { Samples }\end{array}$} & \multirow[b]{2}{*}{ Character } & \multicolumn{13}{|c|}{ XRD-Mineralogy (\%) of the clay fraction quantified with Siroquant Software } \\
\hline & & $\begin{array}{c}\text { K- } \\
\text { felds }\end{array}$ & Illite & Hallo & Kaol & Qtz. & Verm & Lepid & Chlor & $\mathrm{C}-\mathrm{V}$ & Gibb & Anat & $\mathrm{He}$ & Cris. \\
\hline Ox1 & Rock with flux structure & 52.5 & 6.4 & 34.5 & 0.5 & 4.5 & & & & & 1.5 & & & \\
\hline Ox2 & Blocky structure & & 89.3 & 2.1 & 1.7 & & 0.6 & 6.4 & & & & & & \\
\hline Ox3 & Matrix in the regolith & & 11.4 & 44.1 & 35.9 & 7.3 & 1.3 & & & & & & & \\
\hline Ox4 & Vein & & & 54.8 & 42.0 & 1.0 & & & 2.1 & & & & & \\
\hline Ox5 & Matrix in the regolith & & & 70.4 & 24.7 & 1.1 & 0.2 & & 0.6 & & 3 & & & \\
\hline Ox6 & Red Level & & & 65.7 & 24.7 & 1.9 & & 0.6 & & 1.6 & 5.4 & & & \\
\hline Ox7* & Ochre Level & & $\mathrm{x}$ & $\mathrm{x}$ & $\mathrm{x}$ & $\mathrm{x}$ & $\mathrm{x}$ & $\mathrm{x}$ & & & & $\mathrm{x}$ & & \\
\hline Ox8 & Top soil & & & 54.5 & 35.7 & 1.1 & 0.7 & 0.7 & 7.3 & & & & & \\
\hline $\begin{array}{l}\text { Incepa } \\
\text { Samples }\end{array}$ & Character & $\begin{array}{l}\text { K- } \\
\text { felds }\end{array}$ & Illite & Hallo & Kaol & Qtz. & Verm & Lepid & Chlor & $\mathrm{C}-\mathrm{V}$ & Gibb & Anat & $\mathrm{He}$ & Cris. \\
\hline Inc1 & Vein in the saprock & & & 50.9 & 49.1 & & & & & & & & & \\
\hline Inc2a & Saprock & & 20.9 & 43.7 & 22.1 & 13.2 & & & & & & & & \\
\hline Inc2b* & Grey Saprock & & $\mathrm{x}$ & $\mathrm{x}$ & $\mathrm{x}$ & $\mathrm{x}$ & $\mathrm{x}$ & & & & & & & \\
\hline Inc3* & Clayey matrix & & $\mathrm{x}$ & $\mathrm{x}$ & $\mathrm{x}$ & $\mathrm{x}$ & $\mathrm{x}$ & & & & & & & \\
\hline Inc4a & Laminated matrix & & & 77.6 & 21.9 & 0.1 & 0.5 & & & & & & & \\
\hline Inc4b & Brittle laminated matrix & & & 79.7 & 14.7 & 5.6 & & & & & & & & \\
\hline Inc5 & White granular structure & & & 27.6 & 69.9 & 2.4 & 0.2 & & & & & & & \\
\hline $\begin{array}{l}\text { Ceramarte } \\
\text { Samples } \\
\end{array}$ & Character & $\begin{array}{c}\text { K- } \\
\text { felds }\end{array}$ & Illite & Hallo & Kaol & Qtz. & Verm & Lepid & Chlor & $\mathrm{C}-\mathrm{V}$ & Gibb & Anat & $\mathrm{He}$ & Cris. \\
\hline Celav & Vein in the rock & & & 68.2 & 26.7 & 5.1 & & & & & & & & \\
\hline Ce2av & Vein in the saprock & & & 44.2 & 55.1 & 0.7 & & & & & & & & \\
\hline $\mathrm{Ce} 2 \mathrm{~m}$ & Saprock matrix & 48.0 & & 36.0 & 8.3 & 7.7 & & & & & & & & \\
\hline Ce3av & Vein in the saprock & & & 54.4 & 45.6 & & & & & & & & & \\
\hline $\mathrm{Ce} 3 \mathrm{~b}$ & Saprock matrix & 32.3 & & 48.7 & 14.2 & 4.8 & 0.1 & & & & & & & \\
\hline Ce4acd & Vein in Oxidized facies & & & 69.3 & 28.3 & 1.3 & & 0.9 & & & & & & \\
\hline $\mathrm{Ce} 5 \mathrm{a}$ & Clayey level & & & 90.8 & 7.2 & 1.7 & 0.4 & & & & & & & \\
\hline Ce6a & Vein & & & 58.9 & 36.5 & 3.5 & 0.3 & 0.8 & & & & & & \\
\hline Ce6b & Matrix of the saprolite & & & 51.8 & 41.2 & 1.6 & 0.2 & & 0.2 & & & & & 5.2 \\
\hline Ce6c & Vein & & & 57.5 & 41 & 1 & 0.4 & & 0.2 & & & & & \\
\hline $\mathrm{Ce} 7$ & Upper saprolite & & & 60.7 & 36.4 & 3.2 & & & & & & & & \\
\hline $\mathrm{Ce} 9$ & Pallid Zone & & & 49.2 & 48.2 & 2.5 & & & & & & & & \\
\hline $\mathrm{Ce} 10$ & Pallid Zone & & & 55.5 & 39.7 & 4.9 & & & & & & & & \\
\hline
\end{tabular}

*samples that were not quantifiable with siroquant, $\mathrm{x}$ represents the mineralogy of the clay fraction, K-felds $=$ K-Feldspar, Illite/I-S = Illite or Illite-Smectite, Hallo

$=$ Halloysite, Kaol $=$ Kaolinite, Qtz. $=$ Quartz, Verm $=$ Vermiculite, Lepid $=$ Lepidocrocite, Chlor $=$ Chlorite, $\mathrm{C}-\mathrm{V}=$ Chlorite-Vermiculite, Gib $=$ Gibbsite, Anat $=$

Anatase, $\mathrm{He}=$ Hematite, Crist $=$ Cristobalite.

Chemical analyses of bulk samples showed that the veins have kaolinitic composition, the samples of the matrix have high amounts of $\mathrm{SiO}_{2}$ due to quartz and the green clay of the blocky structures from Oxford Mine has higher $\mathrm{K}_{2} \mathrm{O}$ content than the other samples.

$\mathrm{Fe}_{2} \mathrm{O}_{3}$ contents vary from 3.15 wt. $\%$ in the greenclay sample from Oxford Mine, to $0.185 \mathrm{wt}$. $\%$, in the veins of Incepa Mine.

$\mathrm{TiO}_{2}$ values are from 0.51 to $0.01 \mathrm{wt} . \%$. The lower values are from samples of veins in the base of the mines and the higher ones are from samples from the top of the deposits.

The $\mathrm{K}_{2} \mathrm{O}$ content composition may be a good mea- sure of the degree of the alteration of the primary minerals. The lower the $\mathrm{K}_{2} \mathrm{O}$ value the high alteration degree of the sample. Table IIIb shows the $\mathrm{K}_{2} \mathrm{O}$ content of the clay fraction from samples from Ceramarte Mine, Incepa Mine and Oxford Mine. It indicates that Ceramarte Mine has a high degree of alteration but not the highest because at Incepa and Oxford the presence if illite, which is more resistent than $\mathrm{K}$-feldspar (of Ceramarte), may invalidate this measure of comparison.

Figure 4 shows the relation between $\mathrm{K}_{2} \mathrm{O}$ content and the position of the samples of Table IIb in the profiles. Samples of Ceramarte Mine are heterogeneous; the veins have low values and the matrix has decreas- 
A

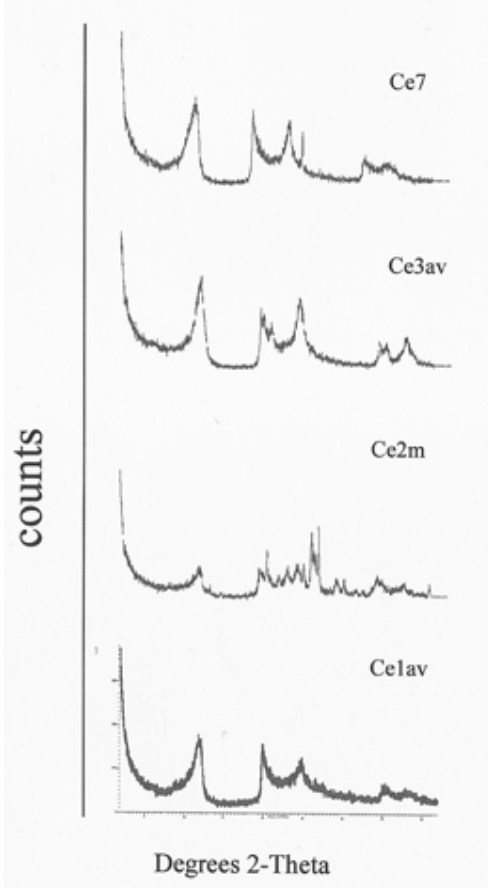

B

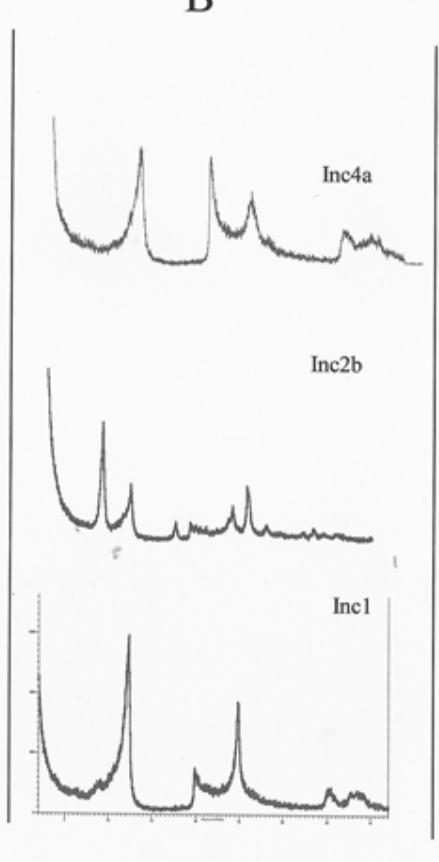

Degrees 2-Theta
$\mathrm{C}$

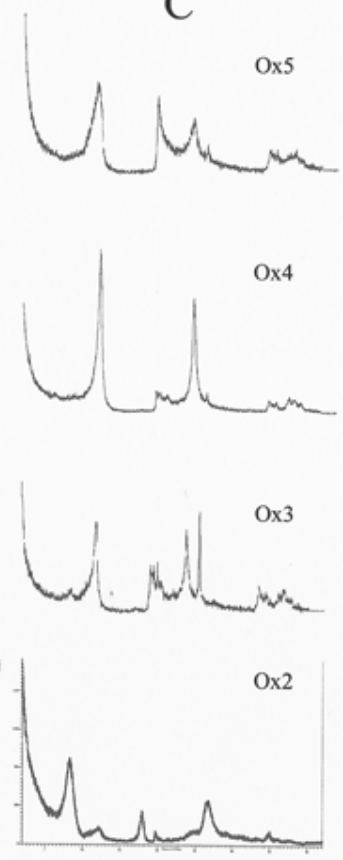

Degrees 2-Theta

Fig. 3 - XRD-Mineralogical Composition (oriented aggregates) of representative samples of the kaolin clays at A - Ceramarte Mine, B - Incepa Mine, C - Oxford Mine.

TABLE III-a

XRF analysis (wt. \%) of major elements of 11 bulk samples from kaolin clays of Campo Alegre Basin.

\begin{tabular}{c|c|c|c|c|c|c|c|c|c|c|c}
\hline Mine & \multicolumn{9}{|c|}{ Ceramarte } & \multicolumn{3}{c}{ Incepa } & \multicolumn{3}{c}{ Oxford } \\
\hline $\begin{array}{c}\text { Type } \\
\text { of the } \\
\text { sample }\end{array}$ & $\begin{array}{c}\text { Vein in } \\
\text { in the } \\
\text { rock }\end{array}$ & $\begin{array}{c}\text { Vein } \\
\text { in the } \\
\text { saprock }\end{array}$ & $\begin{array}{c}\text { Clayey } \\
\text { level } \\
\text { matrix }\end{array}$ & $\begin{array}{c}\text { Vein } \\
\text { in the } \\
\text { matrix }\end{array}$ & $\begin{array}{c}\text { Upper } \\
\text { saprolite } \\
\text { matrix }\end{array}$ & $\begin{array}{c}\text { Vein } \\
\text { in the } \\
\text { saprock }\end{array}$ & $\begin{array}{c}\text { Laminated } \\
\text { matrix }\end{array}$ & $\begin{array}{c}\text { Brittle } \\
\text { laminated } \\
\text { matrix }\end{array}$ & $\begin{array}{c}\text { Blocky } \\
\text { structure- } \\
\text { green clay }\end{array}$ & $\begin{array}{c}\text { Matrix } \\
\text { in the } \\
\text { regolith }\end{array}$ & $\begin{array}{c}\text { Top } \\
\text { soil }\end{array}$ \\
\hline label. & ce1v & ce3a & ce5 & ce6a & ce7 & inc1 & inc4a & inc4b & ox2 & ox5 & ox8 \\
\hline $\mathrm{SiO}_{2}$ & 45.56 & 45.05 & 70.11 & 52.01 & 75.22 & 45.89 & 68.42 & 60.32 & 49.49 & 67.63 & 59.17 \\
\hline $\mathrm{Al}_{2} \mathrm{O}_{3}$ & 36.63 & 35.80 & 19.25 & 32.96 & 15.80 & 37.74 & 20.18 & 26.42 & 30.16 & 21.86 & 27.14 \\
\hline $\mathrm{Fe}_{2} \mathrm{O}_{3}$ & 0.84 & 2.12 & 0.45 & 0.58 & 0.41 & 0.19 & 0.50 & 0.29 & 3.15 & 0.35 & 1.03 \\
\hline $\mathrm{MgO}$ & 0.04 & 0.15 & 0.03 & 0.04 & 0.03 & 0.06 & 0.04 & 0.04 & 0.94 & 0.08 & 0.24 \\
\hline $\mathrm{MnO}$ & 0.00 & 0.01 & 0.00 & 0.00 & 0.00 & 0.00 & 0.00 & 0.00 & 0.04 & 0.00 & 0.01 \\
\hline $\mathrm{TiO}_{2}$ & 0.02 & 0.02 & 0.51 & 0.17 & 0.36 & 0.01 & 0.26 & 0.38 & 0.29 & 0.28 & 0.29 \\
\hline $\mathrm{CaO}$ & 0.00 & 0.00 & 0.01 & 0.00 & 0.01 & 0.00 & 0.01 & 0.01 & 0.00 & 0.01 & 0.01 \\
\hline $\mathrm{Na}_{2} \mathrm{O}$ & 0.17 & 0.01 & 0.00 & 0.02 & 0.03 & 0.00 & 0.01 & 0.02 & 0.02 & 0.01 & 0.02 \\
\hline $\mathrm{K}_{2} \mathrm{O}$ & 0.10 & 0.08 & 0.04 & 0.04 & 0.06 & 0.18 & 0.26 & 0.15 & 5.95 & 0.30 & 0.90 \\
\hline $\mathrm{P}_{2} \mathrm{O}_{5}$ & 0.15 & 0.01 & 0.03 & 0.04 & 0.03 & 0.00 & 0.02 & 0.03 & 0.01 & 0.03 & 0.01 \\
\hline $\mathrm{S}$ & 0.00 & 0.01 & 0.00 & 0.00 & 0.00 & 0.01 & 0.01 & 0.01 & 0.00 & 0.01 & 0.01 \\
\hline $\mathrm{Total}$ & 83.52 & 83.25 & 90.42 & 85.86 & 91.95 & 84.06 & 89.70 & 87.66 & 90.06 & 90.56 & 88.82 \\
\hline
\end{tabular}

ing values from base to the top of the profile. At Incepa the samples have decreasing $\mathrm{K}_{2} \mathrm{O}$ values from base to the surface but not sample 1 that is from a vein. The samples from Oxford Mine also have decreasing $\mathrm{K}_{2} \mathrm{O}$ values from base to the surface; sample 7 (Ox7) doesn't follow this trend, because it still has some illite. The av- 
TABLE III-b

$\mathrm{XRF}$ analysis (wt. \%) of $\mathrm{K}_{2} \mathrm{O}$ clay fractions of samples from kaolin clays of Campo Alegre Basin.

\begin{tabular}{c|c|c||c|c|c||c|c|c}
\hline & \multicolumn{2}{|c||}{ Ceramarte } & & \multicolumn{2}{c||}{ Incepa } & \multicolumn{2}{c}{ Oxford } \\
\hline 1 & Ce1v & 0.31 & 1 & inc1 & 0.22 & 1 & Ox1 & 4.46 \\
\hline 2 & Ce2a & 5.46 & 2 & inc2b & 4.41 & 2 & Ox 2 & 6.99 \\
\hline 3 & Ce2b & 0.19 & 3 & inc2a & 1.72 & 3 & Ox 3 & 1.16 \\
\hline 4 & Ce3a & 0.14 & 4 & inc3 & 1.42 & 4 & Ox 4 & 0.33 \\
\hline 5 & Ce3b & 2.97 & 5 & inc 4a & 0.13 & 5 & Ox 5 & 0.18 \\
\hline 6 & Ce4a & 0.02 & 6 & inc4b & 0.09 & 6 & Ox 6 & 0.19 \\
\hline 7 & Ce4b & 0.06 & 7 & inc5 & 0.71 & 7 & Ox 7 & 2.84 \\
\hline 8 & Ce5a & 0.01 & & & & 8 & Ox 8 & 0.80 \\
\hline 8 & Ce6a & 0.03 & & & & & & \\
\hline 10 & Ce6b & 0.03 & & & & & & \\
\hline 11 & Ce7 & 0.03 & & & & & & \\
\hline \multicolumn{10}{|c|}{ Average } & 1.11 & & Average & 1.24 & & Average & 1.35 \\
\hline
\end{tabular}

erage $\mathrm{K}_{2} \mathrm{O}$ content of the clay fraction from Ceramarte Mine is 0.97 wt. \%; of Incepa Mine is 1.24 wt. \%, and of Oxford Mine is 1.34 wt. \%.
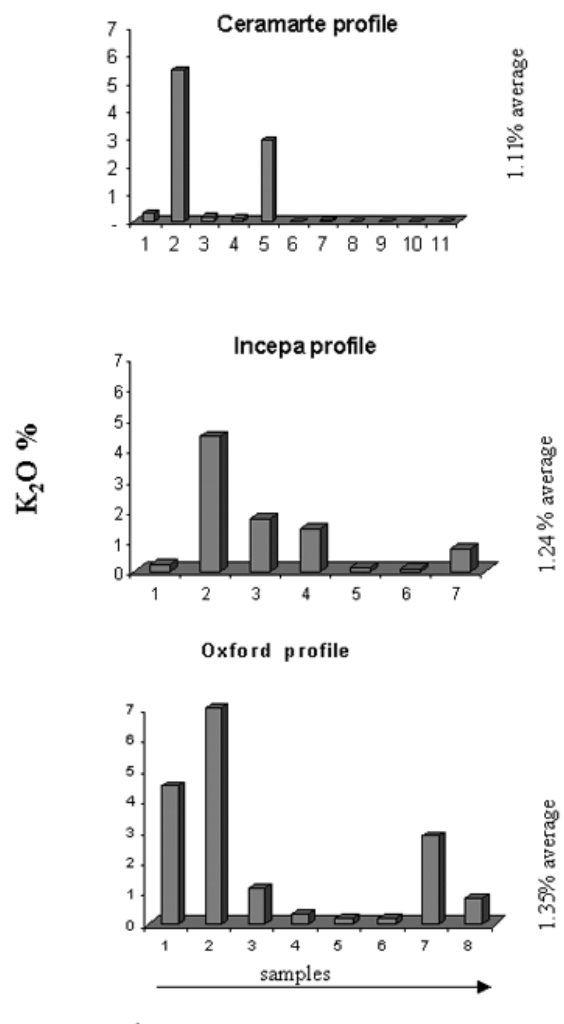

base top

Fig. $4-\mathrm{K}_{2} \mathrm{O}$ content used as a measure of the degree of the alteration of the primary minerals in the mines.
There is a positive correlation between CEC and depth in the Ceramarte Mine (Fig. 5 and Table III) as already seen with $\mathrm{K}_{2} \mathrm{O}$ content, but not for the other mines. The average CEC of Oxford Mine clays is the highest (11.2 meq/100g) and may be related to the presence of some Illite-Smectite. The average CEC of Ceramarte clays $(10.3 \mathrm{meq} / 100 \mathrm{~g})$ may be due to the observed very small length of halloysite tubes (mode $0.46 \mu \mathrm{m}$ in the veins of the rock; $0.22 \mu \mathrm{m}$ in the veins of the alterite). Clays from Incepa Mine have the lowest CEC average value $(5.6 \mathrm{meq} / 100 \mathrm{~g})$, possibly related to the highest tube width (mode $0.46 \mu \mathrm{m}$ ).

\section{Microtextures of the Clays AND Elemental Composition}

Visible differentiations from the walls of each mine (Table I) were sampled. SEM observations and EDX Analysis of the small fragments and the thin sections were done in order to add new data on the mineralogy and composition of the bulk samples (Table IV).

Ceramarte Mine facies are composed of tubular halloysite and platy xenomorphic crystals of kaolinite $(\mathrm{Si}=\mathrm{Al})$, with tubes predominating in the matrix, with few spheres, and platy xenomorphic crystals of kaolinite forming (iron-rich) stacks in the veins $(\mathrm{Ce} 2 \mathrm{v})$. The iron was detected by the EDX Analyses with the SEM (Fig. 6). Exceptions are some hard white veins of halloysite in the rhyolite where platy crystals were not ob- 
TABLE IV

Distribution of mineralogy and elemental composition (EDS) of the clay particles observed with SEM, pursuing macroscopical differentiation in the wall of the mines.

\begin{tabular}{|c|c|c|c|c|c|c|c|}
\hline $\begin{array}{c}\text { Weathering } \\
\text { profile }\end{array}$ & \multicolumn{2}{|c|}{$\begin{array}{l}\text { Clay minerals at } \\
\text { Ceramarte Mine }\end{array}$} & \multicolumn{2}{|c|}{$\begin{array}{l}\text { Clay minerals at } \\
\text { Incepa Mine }\end{array}$} & \multicolumn{2}{|c|}{$\begin{array}{c}\text { Clay minerals at } \\
\text { Oxford Mine }\end{array}$} & $\begin{array}{l}\text { SEM observations and } \\
\text { EDX analysis }\end{array}$ \\
\hline $\begin{array}{l}\text { Disturbed } \\
\text { saprolite } \\
\text { and veins }\end{array}$ & 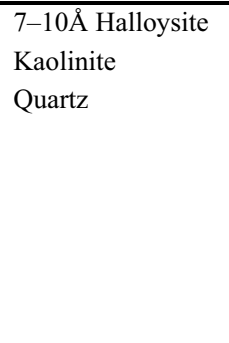 & $\begin{array}{l}(60.3) \\
(36.4) \\
(3.2)\end{array}$ & $\begin{array}{l}\text { Kaolinite } \\
10 \AA-7 \AA ̊ \text { Hallo } \\
\text { Vermiculite } \\
\text { Quartz }\end{array}$ & $\begin{array}{l}(71.2) \\
(26.2) \\
(0.7) \\
(1.9)\end{array}$ & $\begin{array}{l}10 \AA ̊-7 \AA \text { Hallo } \\
\text { Kaolinite } \\
\text { Anatase } \\
\text { Vermiculite } \\
\text { Quartz } \\
\text { Gibbsite }\end{array}$ & $\begin{array}{l}(54.4) \\
(35.7) \\
(7.3) \\
(0.7) \\
(1.1) \\
(0.7)\end{array}$ & $\begin{array}{l}\text { Kaolinite plates are dominant in } \\
\text { the veins, with some amount } \\
\text { of } \mathrm{Fe} \\
\text { Chemical components of clays } \\
\text { of the matrix are } \mathrm{Si}, \mathrm{Al} \text {, } \\
\mathrm{Fe}, \mathrm{Ti} \\
\text { Clays of veins at the base of } \\
\text { Oxford Mine have low } \\
\text { amounts of } \mathrm{Mg}, \mathrm{Ti}, \mathrm{Pb}\end{array}$ \\
\hline Saprock & 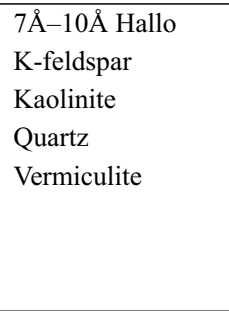 & $\begin{array}{l}(48.7) \\
(32.3) \\
(14.2) \\
(4.8) \\
(0.1)\end{array}$ & 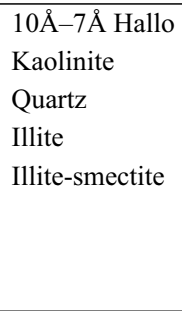 & $\begin{array}{l}(43.7) \\
(22.1) \\
(13.2) \\
(12.8) \\
(8.1)\end{array}$ & $\begin{array}{l}\text { K-feldspar } \\
\text { 10-7Å Hallo } \\
\text { Mica } \\
\text { Quartz } \\
\text { Gibbsite } \\
\text { Kaolinite }\end{array}$ & $\begin{array}{l}(52.5) \\
(34.5) \\
(6.4) \\
(4.5) \\
(1.5) \\
(0.5)\end{array}$ & $\begin{array}{l}\text { Inherited minerals weathers with } \\
\text { different rates, } \mathrm{K} \text {-feldspar } \\
\text { appears with etch pit } \\
\text { formations } \\
\text { Chemical components of illitic } \\
\text { clays are } \mathrm{Si}, \mathrm{Al}, \mathrm{K}, \mathrm{Fe} \text { and } \\
\text { very few amounts of } \mathrm{Mg}, \\
\mathrm{Zr} \text { and } \mathrm{Ti}\end{array}$ \\
\hline
\end{tabular}

served (Ce1Av). Inherited grains of K-feldspar appear at the base of the mine showing differential alteration as "etch-pit formation" (Fig. 7A), but disappear throughout the top. The spherulitic texture of the rhyolite, due to crystallization of the volcanic glass, is also observed in the samples from the base of the Mine both in thin section and in small fragments and is related to the very fast cooling rate of the high temperature acid flows. The arrow in the thin section photomicrograph (Fig. 7B) points the spherulitic texture of the rhyolite. In a small fragment the porous structure of the spherulite, made of neddles of quartz (Fig. 7C) contains halloysite aggregates.

In the pallid zone of Ceramarte Mine an aggregate of halloysite tubes that apparently merge into kaolin stacks was observed (Fig. 7D).

Incepa Mine facies are composed of tubular and platy xenomorphic crystals of halloysite and kaolinite ( $\mathrm{Si}, \mathrm{Al})$, some platy xenomorphic crystals of illite ( $\mathrm{Si}>$ $\mathrm{Al} \gg \mathrm{K}>\mathrm{Fe}$ ), and laths of Vermiculite. Some relicts of the rock (aphanite) are indurated with quartz box-work.

A finely laminated white and pale red facies at $4 \mathrm{~m}$ depth from the surface is seen by SEM to be caused by layers of halloysite tubes and spheres intercalated with kaolinite plates (Fig. 7E).

Oxford Mine displays the greatest diversity of clay particles. The Gley 8/5BG clays with the blocky structure (16 m depth) showed dominantly platy xenomorphic crystals of illite $(\mathrm{Si}>\mathrm{Al} \gg \mathrm{K}>\mathrm{Fe})$, little illitic material of platy xenomorphic crystals without iron $(\mathrm{Si}>\mathrm{Al} \gg \mathrm{K})$ and lath-shaped crystals with irregular ends $(\mathrm{Si}>\mathrm{Al} \gg \mathrm{K}>\mathrm{Fe})$ (Fig. 7F). Also small amounts of $\mathrm{Mg}$, Ti and $\mathrm{Zr}$ were detected in these clays. 
A

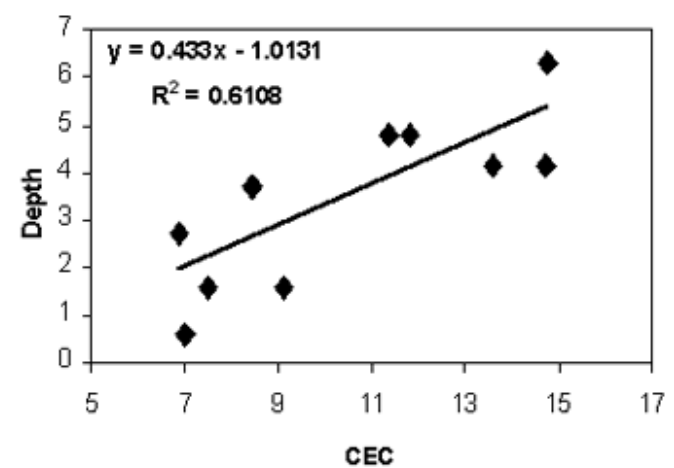

B

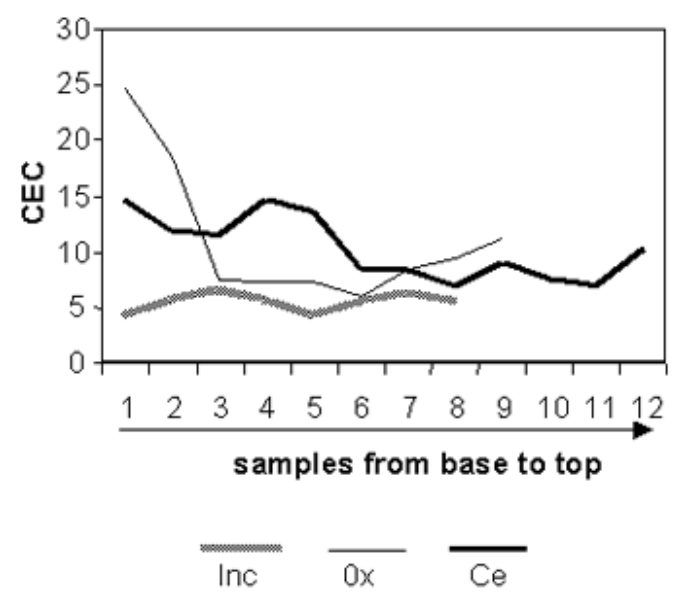

Fig. 5 - (A) correlation between CEC of the clays and depth in Ceramarte Mine and (B) the variation of CEC with depth in the three Mines.

The wall of the mine (matrix) is a light greenishgray clay composed of tubular and platy xenomorphic crystals of halloysite and kaolinite ( $\mathrm{Si}, \mathrm{Al})$, pyramidal crystals of quartz (beta-form), platy xenomorphic crystals of illite $(\mathrm{Si}>\mathrm{Al} \gg \mathrm{K}>\mathrm{Fe})$ and lath-shaped crystals with irregular ends $(\mathrm{Si} \gg \mathrm{Al})$.

The white veins in the wall (11 m depth) are composed of platy xenomorphic crystals of kaolinite, tubes of halloysite $(\mathrm{Si}=\mathrm{Al})$ and platy xenomorphic crystals of illite $(\mathrm{Si}>\mathrm{Al} \gg \mathrm{K}>\mathrm{Fe})$. These clays also showed very small amounts of $\mathrm{Mg}$, and $\mathrm{Ti}$ and $\mathrm{Pb}$.

The red level ( $2 \mathrm{~m}$ depth) is composed of tubes of halloysite $(0.3 \mu \mathrm{m}$ width $)$ and platy xenomorphic crystals of halloysite and kaolinite. Other components as

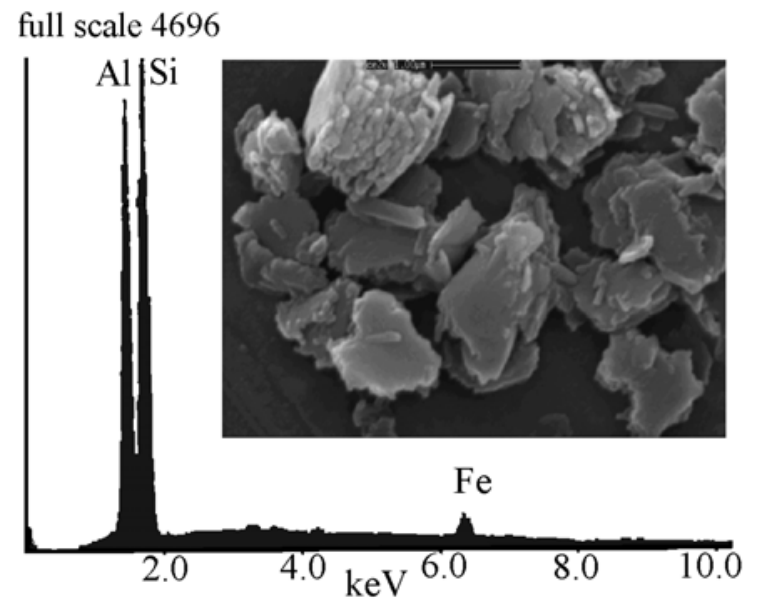

Fig. 6 - Iron-rich platy crystals of kaolinite forming stacks in the veins $(C E 2 v)$. The iron was detected by the EDX Analyses with the SEM.

hematite and anatase were not observed at this scale of magnification (9.000-14.000 x).

Finally the yellowish brown level (1.5 m depth) almost at the top of mine is composed of tubes and platy xenomorphic crystals $(\mathrm{Si}=\mathrm{Al}>\mathrm{Fe} \gg \mathrm{K}>\mathrm{Ti})$ of halloysite and kaolinite. The Fe and Ti detected in these particles may be related to very small amounts of lepidocrocite and anatase observed in the XRD analysis.

The white soil (Gley $8 / \mathrm{N}$ ) at $1 \mathrm{~m}$ depth is composed of tubes and platy xenomorphic crystals of halloysite and kaolinite and small quantity of laths with regular ends $(\mathrm{Si}>\mathrm{Al} \gg \mathrm{K}>\mathrm{Fe}$ or $\mathrm{Si}=\mathrm{Al} \gg \mathrm{Ti}>\mathrm{Fe})$ of vermiculite. Also Ti (anatase) was detected mixed in the clays.

\section{Morphology of the PARTICles}

Halloysite exhibits tubular, spherical and cone-shaped morphologies throughout the clay fraction $(<2 \mu \mathrm{m})$ of the three mines. Arrows of Figure 8 points to: Tubes are the most common, and they often show some flat surfaces (Fig. 8A). There are very small $(0.14 \mu \mathrm{m})$ tubes (Fig. $8 \mathrm{~B})$, short tubes $(0.8 \mu \mathrm{m})$, and long tubes $(3 \mu \mathrm{m})$. The spherical halloysite appears in all the three mines. The spheres are very small $(<0.5 \mu \mathrm{m})$ and are interspersed with the other particles (Fig. 8C), except in the Incepa Mine, where they form layers. Cone morphology and partly rolled tubes were also observed (Fig. 8D).

The planar faces of some halloysite tubes (Fig. 9A) were also investigated through observations of the cross- 
A

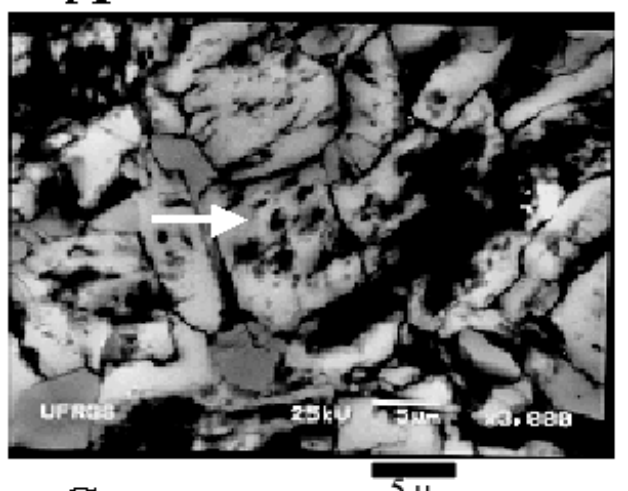

C

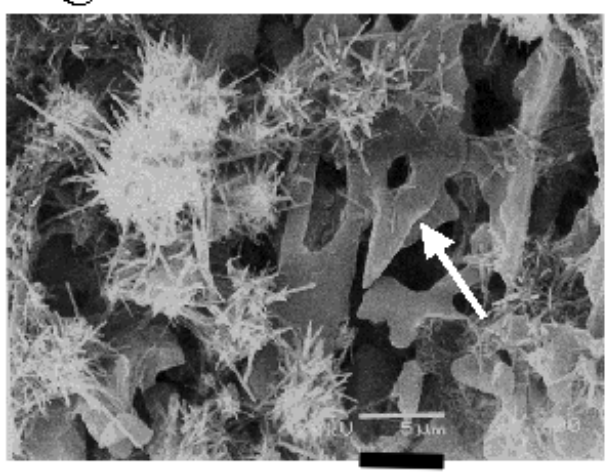

E

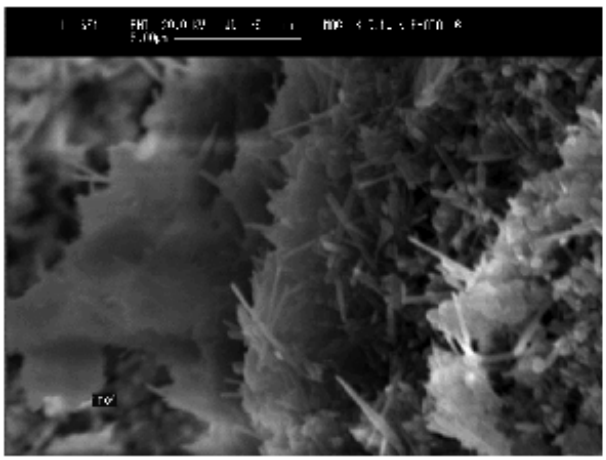

B
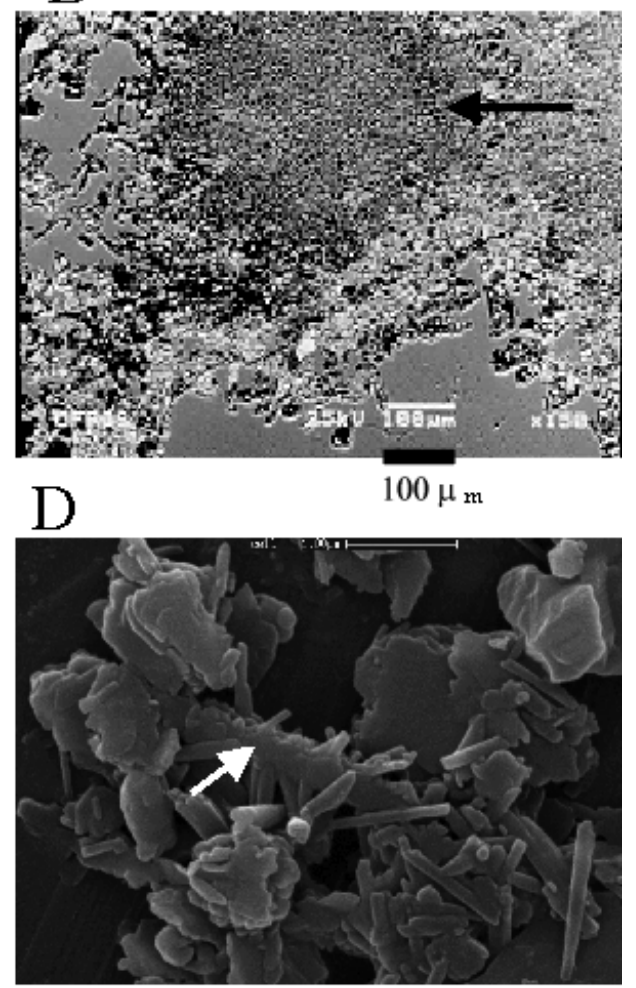

F

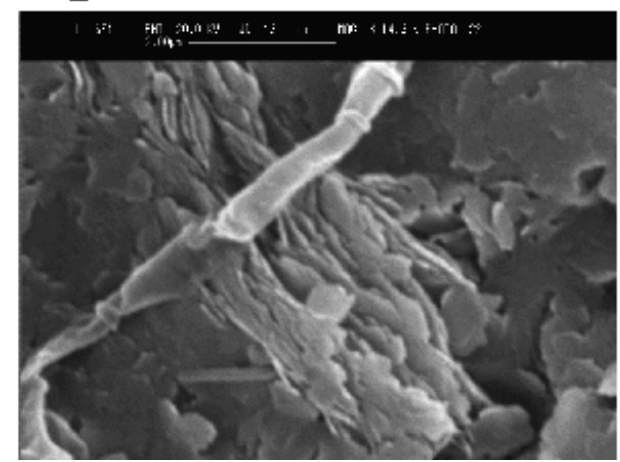

Fig. 7 - Microtextures of the clays: (A) inherited grains of K-feldspar at the base of Ceramarte mine showing "etch-pit formations"; (B) the arrow in the thin section photomicrograph points the spherulitic texture of the rhyolite; (C) in a small fragment, the porous structure of the spherulite, made of neddles of quartz, contains halloysite aggregates; (D) in the pallid zone of Ceramarte Mine it was observed that an aggregate of halloysite tubes apparently merge into kaolin stacks; (E) the stratification at Incepa saprolite is due to layers of halloysite tubes and spheres intercalated with kaolinite plates; (F) blocky structures in Oxford mine showed platy xenomorphic crystals of illite and also lath-shaped crystals with irregular ends. Photomicrographs D, E and F have graphic scale $=1 \mu \mathrm{m}$.

sections of tubes. TEM showed different types of crosssections: i) mixed curved and linear external shape with a circular internal hole and pores between the smoothly curved layers (Fig. 9B), polygonal with a polygonal in- ternal hole (Fig. 9C), ii) partly unrolled (or partly rolled) cross sections (Fig. 9D). Also circular cross-sections with pores between the smoothly curved layers (Fig. 9E) were observed. 

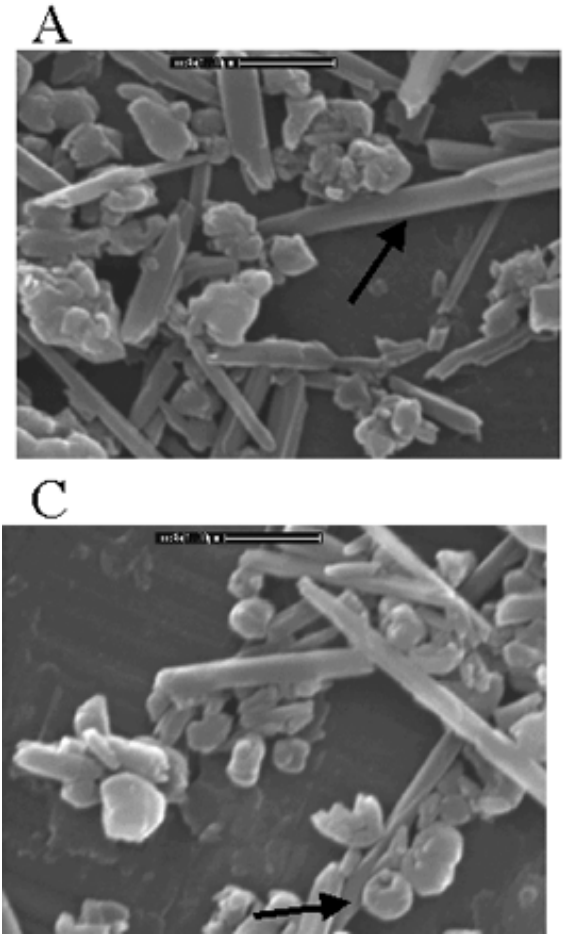

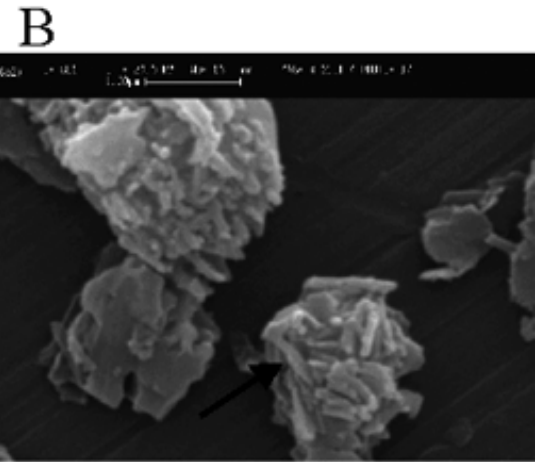

D

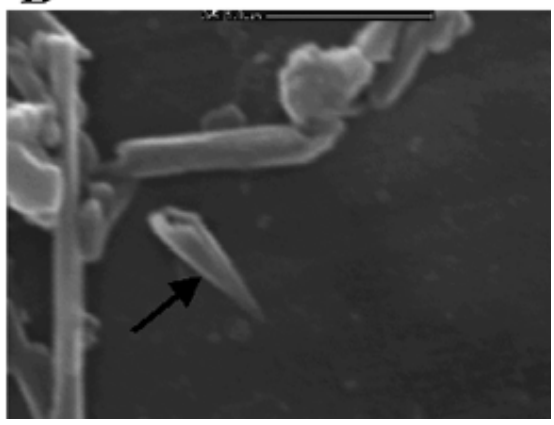

Fig. 8 - Variety of halloysite morphologies: tubes (A), small tubes between kaolinite plates (B), spheres that are scarce (C) and partly rolled tube or cone (D). Graphic Scale $=1 \mu \mathrm{m}$.

\section{Measurements of Halloysite Particles}

The clay separates of three samples of Ceramarte Mine were chosen because of their different values of CEC and because of their location in the profile. One sample of Incepa Mine that showed a low CEC value (4.4) was also statistically analyzed in order to obtain quantitative morphological data of the length and width of the halloysite particles. Also a sample from Oxford mine was analyzed. Statistic data are recorded in micrometers in Table V. Sample Ce1v is from white clays in a vein in the saprock, $\mathrm{Ce} 2 \mathrm{v}$ is from very pale brown clay in a vein in the saprolite; sample Inc4a,b is from a laminated matrix of Incepa Mine. Also the clay sample Ce9 that is from the upper pallid zone was analyzed. Curves representing the minimum, mean, median, mode and maximum tube length for each sample are in Figure 10A and tube width in Figure 10B.

Figure 10A shows that particles of sample CE2v have the lowest statistical values of the four samples, except the value of max length. Particles of sample Inc4a,b have the highest statistical values of the four samples, except the value of mode length.

Figure 10B also shows that particles of sample CE2v have the lowest statistical values of the four samples, except the value of max width. Particles of sample Inc $4 a, b$ have the highest value of maximum width.

\section{Coexistence of Halloysite and Kaolinite}

Halloysite and kaolinite coexist in Campo Alegre as well as in several other kaolin deposits (Murray and Keller 1993). Why both minerals occur? Is there any relationship between halloysite and kaolinite with different precursors? Are they related to different microenvironments? Jeong (1998) observed that genetic relation between the two minerals in the weathering environment is rarely established.

Felsic rocks of Campo Alegre Basin show little mineralogical variation: sanidine and quartz phenocrysts are ubiquitous; arfvedsonite and iron oxides may be present; the matrix is a fine-grained quartz feldspar aggregate. As K-feldspar is the major primary alumino-sili- 
A

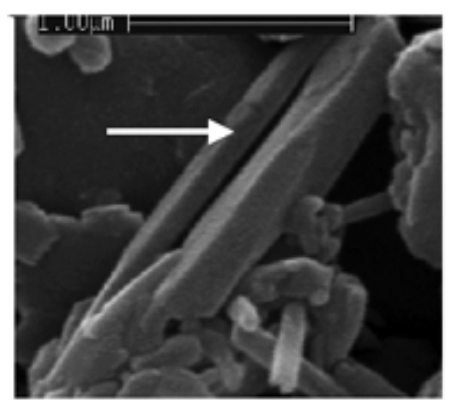

$\mathrm{D}$

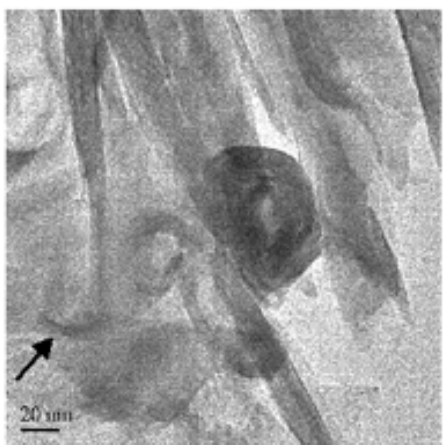

B

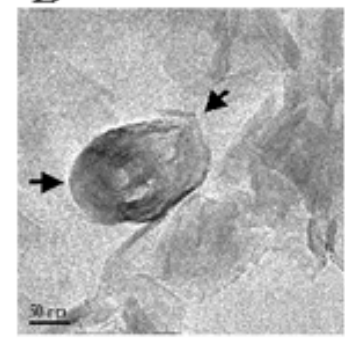

$50 \mathrm{~nm}$

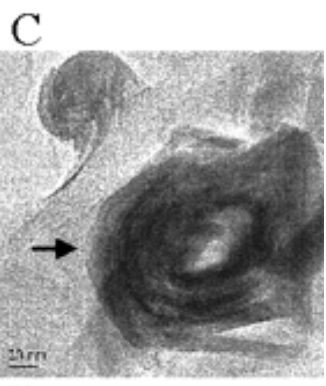

$20 \mathrm{~nm}$

$\mathrm{F}$

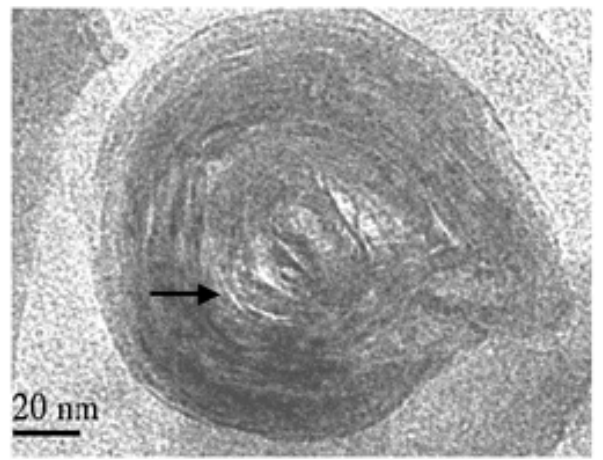

Fig. 9 - Tubes are the most common morphology for halloysite observed using SEM. Planar surface (A) are common. TEM observations of cross-sections of the tubes showed curved shape as well as polygonal shape in the same particle (B). Other cross sections of tubes are polygonal (C). Some unrolled cross sections form plates (D). Also circular cross-sections with pores between the smoothly curved layers (E) were observed.

cate of the rocks, it can be assumed it is the kaolin precursor. Under conditions of good drainage in the humid tropics, K-feldspar weathers to give hollow tubes of halloysite (Parham 1969). Also Banfield and Eggleton (1990) observed a mineralogical pathway in K-feldspar weathering, starting in etch pits and cracks with the formation of cell-textured materials of allophane composition, smectite, a second protocrystalline material and spherical halloysite. After dissolution formed networks of cavities, $\mathrm{Al}$ and $\mathrm{Si}$ precipitated from solution and resulted the growth of tubular halloysite.

The origin of the kaolinite needs other interpretations. In Campo Alegre kaolin deposits, kaolinite occurs as (iron-rich) stacks filling veins either in the rocks or in the saprolite, or as tight aggregates in the saprolite. At Incepa and Oxford Mines also illite and illite-smectite (inherited from pyroclastic rocks) are mixed in the matrix and could be remaining of a hydrothermal process.
Banfield and Eggleton (1990) showed that kaolinite develops from an illitic material $-(\mathrm{Si}>\mathrm{Al} \gg \mathrm{K}>\mathrm{Fe})$ by crystallizing epitactically. The weathering releases $\mathrm{K}$ and the crystals acquire irregular shape and small quantities of iron. But there is no muscovite or illitic material at Ceramarte Mine to explain kaolinite origin. In this case, the veins, where iron-rich kaolinite occurs, are microenvironments of highly weathered material inherited from the top of the weathering profile. Kaolinite appears in stacks with small halloysite tubes between the kaolinite plates. In an experimental transformation, Singh and MacKinnon (1996) caused hydrated Georgia kaolinite plates to roll, forming tubes with both smoothly curved layers and planar faces, as is commonly observed in natural halloysites. Kaolinite rolling in the solid state was observed in natural samples by Robertson and Eggleton (1991) ascribed to transitional forms between kaolinite and halloysite. The reverse case, unrolling of hal- 

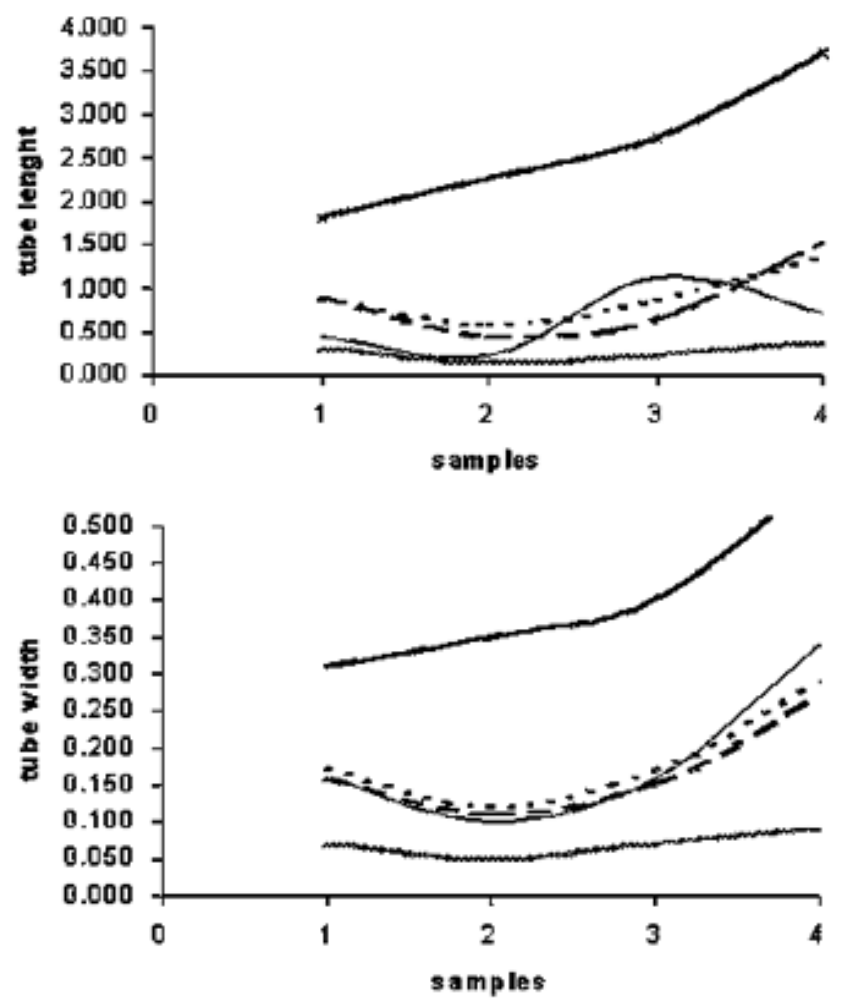

Fig. 10 - Maximum (upper line), mean (dotted line), mode (fine line), median (dashed line) and minimum (lower line) tube lengths and the same statistic values of tube widths of samples 1 (Ce1), 2 (Ce2), 3 (Ce9), and 4 (Inc4a-b).

loysite tubes, is also possible. Singh (1996) explained how the 1:1 structure switches from halloysite to kaolinite: as a result of prolonged dehydration, hydrogen bonding between layers gradually became stronger, and the structure shifts from rolling mechanism to tetrahedral rotation, causing tubes to produce laths by unrolling. Wouatong et al. (1996) observed this morphological transformation (unrolled spherical-shaped halloysite to tubular and finally unrolled again producing platy kaolinite) in a granite saprolite. Present study observed the following sequence of morphological changes in halloysite particles (Fig. 11) in a weathering profile: Tubes - Tubes with planar faces and internal cylindrical holes - Tubes with planar faces and internal hole with planar walls-unrolled tubes-plates. The correlation of the forms with depth is not linear. All the forms occur along the weathering profile, but the transitional forms between tubes and plates were observed most frequently in the samples near the surface.
The end members of the solid-state halloysite to kaolinite transformation at Campo Alegre basin are low Hinckley Index and very broad basal peaks kaolinites, similar to the end-members kaolinites described by Jeong (1998). All observations agree that halloysite is a metastable mineral at Campo Alegre basin, and transform to stable kaolinite with aging (weathering).

\section{CONCLUSIONS}

This study resulted in the following conclusions:

- The kaolin from Campo Alegre Basin is composed of halloysite (10 $\AA$ and $7 \AA$ ) and disordered kaolinite. Halloysite content is higher than kaolinite, except in some veins; low abundant minerals are quartz, K-feldspar, illite, illite-smectite, vermiculite, anatase, hematite and lepidocrocite.

- K-feldspar weathering is the starting point of the halloysite formation as hollow tube particles with 


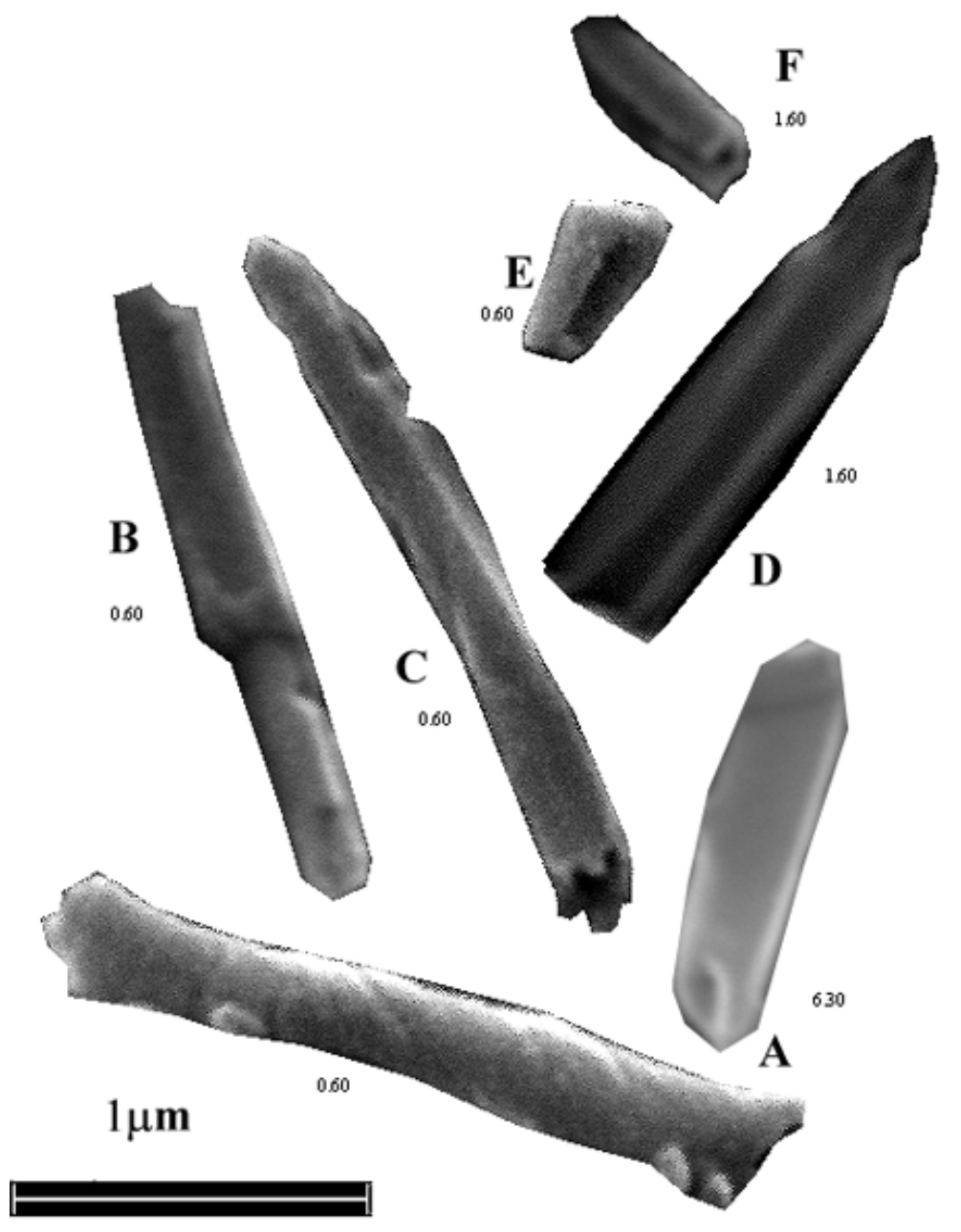

Fig. 11 - Observed morphological changes in the halloysite particles: Tubes (A), tubes with planar faces with internal cylindrical holes $(B)$, tubes with internal and external planar faces $(C)$, unrolling tubes $(\mathrm{D}, \mathrm{E}$, F). The sequence of changes in morphology $(A \rightarrow B \rightarrow C \rightarrow D \rightarrow E)$ due to dehydration of halloysite, evolves into platy kaolin particles. Small numbers correspond to position in meters of depth in the profile.

both rounded and polygonal cross-sections. The planar faces of the tubes with polygonal cross-sections are due to dehydration.

- Kaolinite is interpreted to have two likely origins: the weathering of illitic material from pyroclastic rocks (Incepa and Oxford Mine) and the dehydration of halloysite at or near the upper part of the weathering profiles. The observed sequence of morphological changes in halloysite to kaolinite particles is - tubes - tubes with planar faces and internal cylindrical holes - tubes with planar faces and internal hole with planar walls - unrolled tubes - plates.

\section{ACKNOWLEDGMENTS}

The authors thank Electronic Microscopy Unit of the Australian National University, Dr David Lewellyn help with the TEM, Robin Westcott and Alain Meunier.

\section{RESUMO}

O caolim da Bacia de Campo Alegre, Estado de Santa Catarina, Brasil, formou-se da alteração de rochas vulcânicas ácidas. A haloisita predomina na fração argila da matriz do corpo de caolim, enquanto a caolinita, de baixa cristalinidade, é abundante nos veios. Algumas estruturas em blocos, primários, têm altos teores de ilita em uma mina, mas no geral, somente 
TABLE V

Measurements of the area, length and width of halloysite tube particles in SEM photomicrographs, from 3 samples of the Ceramarte Mine, and two samples of Incepa Mine, measured with NIH software.

\begin{tabular}{|c|c|c|}
\hline $\begin{array}{c}\text { Ce1 } \\
\text { (104 particles) }\end{array}$ & $\begin{array}{l}\text { tube length } \\
\qquad(\mu \mathrm{m})\end{array}$ & $\begin{array}{l}\text { tube width } \\
\qquad(\mu \mathrm{m})\end{array}$ \\
\hline $\min$ & 0.290 & 0.070 \\
\hline $\operatorname{maxi}$ & 1.800 & 0.310 \\
\hline mean & 0.880 & 0.173 \\
\hline mode & 0.460 & 0.160 \\
\hline median & 0.890 & 0.160 \\
\hline standard dev & 0.32172 & 0.04727 \\
\hline $\begin{array}{c}\text { Ce2 } \\
\text { (107 particles) }\end{array}$ & $\begin{array}{l}\text { tube length } \\
\qquad(\mu \mathrm{m})\end{array}$ & $\begin{array}{c}\text { tube width } \\
(\mu \mathrm{m})\end{array}$ \\
\hline $\min$ & 0.130 & 0.050 \\
\hline $\max$ & 2.260 & 0.350 \\
\hline mean & 0.583 & 0.120 \\
\hline mode & 0.220 & 0.100 \\
\hline median & 0.455 & 0.110 \\
\hline standard dev & 0.439042 & 0.049923 \\
\hline $\begin{array}{c}\mathrm{Ce} 9 \\
(74 \text { particles })\end{array}$ & $\begin{array}{l}\text { tube length } \\
\qquad(\mu \mathrm{m})\end{array}$ & $\begin{array}{l}\text { tube width } \\
\qquad(\mu \mathrm{m})\end{array}$ \\
\hline $\min$ & 0.220 & 0.070 \\
\hline $\max$ & 2.730 & 0.400 \\
\hline mean & 0.848 & 0.168 \\
\hline mode & 1.130 & 0.160 \\
\hline median & 0.640 & 0.150 \\
\hline standard dev & 0.5637 & 0.0659 \\
\hline $\begin{array}{c}\text { Inc4 }(\mathrm{a}, \mathrm{b}) \\
(99 \text { particles }) \\
\end{array}$ & $\begin{array}{l}\text { tube length } \\
\qquad(\mu \mathrm{m})\end{array}$ & $\begin{array}{l}\text { tube width } \\
(\mu \mathrm{m})\end{array}$ \\
\hline $\min$ & 0.380 & 0.090 \\
\hline $\max$ & 3.710 & 0.570 \\
\hline mean & 1.363 & 0.287 \\
\hline mode & 0.710 & mode $0.46 \mu \mathrm{m}$ \\
\hline median & 1.520 & 0.270 \\
\hline standard dev & 0.67579 & 0.091444 \\
\hline
\end{tabular}

foram identificadas, na fração argila das amostras, baixas quantidades de ilita-esmectita, ilita, clorita-vermiculita, vermiculita e quartzo. Em direção ao topo das minas aparecem hematita e lepidocrocita em níveis vermelhos e ocres e as quantidades de caolinita aumentam, se comparadas às de haloisita. O zoneamento vertical dos níveis de alteração, as mudanças mineralógicas, a correlação positiva entre profundidade e Capacidade de Troca de Cátions das argilas, a preservação de diferentes tipos de textura de rochas nos corpos de caolim e o predomínio da morfologia tubular da haloisita indicam uma origem supergênica para os depósitos. São discutidos critérios para distinguir entre caolins supergênicos e hipogênicos. A Microscopia Eletrônica de Transmissão das secções transversais dos tubos de haloisita mostrou formas poligonais que são atribuídas a transições entre caolinita e haloisita. Propõe-se que algumas das caolinitas destes depósitos sejam herdadas da desidratação de tubos de haloisita.

Palavras-chave: caolinita, haloisita, morfologia da haloisita, caolim, intemperismo, gênese de argilas.

\section{REFERENCES}

BAnfield J And EgGleton RA. 1990. Analytical Transmission Electron Microscope Studies of Plagioclase, Muscovite, and K-feldspar Weathering. Clays Clay Miner 38: 77-89

Biondi JC, VAnzela GA And BartozeK MK. 1999. Processos químicos de gênese de depósitos de argilominerais a partir de rochas vulcânicas da formação Campo Alegre, SC. Geoch Bras 13: 121-143.

Citroni SB, Basei MAS, Siga Jr O And Neto JMR. 2001. Volcanism and Stratigraphy of the Neoproterozoic Campo Alegre Basin, SC, Brasil. An Acad Bras Cienc 73: 581-597.

Cordani UG, Basei MAS, Siga Jr O And Nutman A. 1999. Idades U-Pb (SHRIPM) de rochas vulcânicas das Bacias de Campo Alegre, Itajai e Castro (SC e PR). Resumos. An Acad Bras Cienc 71: 835.

Daixt EC AND CARvalho MAS. 1980. Projeto Geoquímica na Área de Guaratubinha-Pien, SC. São Paulo: DNPM/ CPRM.

EBERT H. 1971. O grupo Guaratubinha no norte do Estado de Santa Catarina. In: Congresso Brasileiro DE Geologia 25, SBG, São Paulo, SP, Brasil, p. 147-165.

JANIK LJ AND KEELING JL. 1996. Quantitative determination of halloysite using FT-IR PLS analysis and its applicaton to the characterisation of kaolins from northwestern Eyre Peninsula, South Australia. Divisional Report 129. Adelaide: CSIRO Division of Soils, $59 \mathrm{p}$.

JEONG GY. 1998. Formation of vermicular kaolinite from halloysite aggregates in the weathering of plagioclase. Clays Clay Miner 46: 270-279.

Murray HH AND Keller WD. 1993. Kaolins, Kaolins and Kaolins 1-24. In: MURRAY HH, BUNDY WM AND 
HARVEY CC (Eds), Kaolin genesis and utilization. Clay Miner Soc Publ, 341 p.

Oliveira MTG De, Furtado SMA, Formoso MLL AND SCHENATO F. 2000. Alteração de Rochas Vulcânicas Ácidas e Formação de Depósitos de Caolim na Bacia de Campo Alegre, SC, Brasil - Estudo da Mina Ceramarte. Geoch Bras 14: 175-190.

PARHAM WE. 1969. Formation of halloysite from feldspar: Low temperature, artificial weathering versus natural weathering. Clays Clay Miner 17: 13-22.

Potter PE. 1997. The Mesozoic and Cenozoic paleodrainage of South America: a natural history. J South Am Earth Sci 10: 331-344.

ROBERTSON IDM AND EGgLETON RA. 1991. Weathering of granitic muscovite to kaolinite and halloysite and of plagioclase-derived kaolinite to halloysite. Clays Clay Miner 39: 13-126.
SingH B. 1996. Why does halloysite roll? A new model. Clays Clay Miner 44: 191-196.

SINGH B AND MACKINNON DR. 1996. Experimental transformation of kaolinite to halloysite. Clays Clay Miner 44: 825-834.

Weischel B, Lima EF, NARdi LVS And Sommer CA. 2000. The alkaline post-collisional volcanism of Campo Alegre Basin in southern Brazil: petrogenetic aspects. Rev Bras Geocienc 30: 393-396.

Wouatong A, Kitagawa R, Takeno S, Tchoua F and NJOPWOUO D. 1996. Morphological transformation of kaolin minerals from granite saprolite in the Western part of Cameroon. Clay Sci 10: 67-81. 